10.15290/cnisk.2019.02.07.05

DR URSZULA SOKOŁOWSKA

orcid.org/0000-0003-2449-4124

Uniwersytet Medyczny w Białymstoku

\title{
Międzynarodowy Rok Kobiet 1975 na łamach „Kobiety i Życia”
}

\section{Streszczenie}

Do lat 70. XX w. większość publikacji w „Kobiecie i Życiu” oscylowała wokół problematyki typowej dla prasy kobiecej, m.in. macierzyństwa, gospodarstwa domowego oraz poradnictwa. Wraz z poczatkiem lat 70. na łamach periodyku coraz częściej pisano o pozycji społecznej kobiet. Nastapiła intensyfikacja tematyki dotyczącej działalności kobiet w sferze publicznej, w tym aktywności politycznej. Uzależnione było to od ówczesnych przemian na scenie politycznej kraju oraz zmian personalnych w redakcji „Kobiety i Życia”.

Problematykę niskiego udziału kobiet w polityce podejmowano szczególnie często w wydaniach z 1975 r. Przy okazji obchodów Międzynarodowego Roku Kobiet redakcja zachęcała czytelniczki do zaangażowania w sferę polityczna. Wielokrotnie przedstawiano sylwetki polskich działaczek politycznych, jak również kobiet aktywnych publicznie poza granicami Polski.

Słowa kluczowe: prasa kobieca, „Kobieta i Życie”, Polska Rzeczpospolita Ludowa, Międzynarodowy Rok Kobiet, kobiety w przestrzeni publicznej, kobiety w polityce 


\title{
THE 1975 INTERNATIONAL YEAR OF WOMEN IN THE LIGHT OF “KOBIETA I ŻYCIE"
}

\begin{abstract}
Until the 1970s, most publications in Kobieta $i$ Życie [Women and Life] revolved around issues typical of women's press, including maternity, household and counseling. At the beginning of the 1970s, the journal published more and more often about the social position of women. The subject of women's activities in the public sphere, including political activity, intensified. It depended on the changes in the country's political scene and personnel changes at the Kobieta $i$ Życie editorial office.

The issue of women's low participation in politics was particularly often addressed in the 1975 editions. On the occasion of the International Year of Women, the Kobieta $i$ Życie editors encouraged readers to become involved in the political sphere. The silhouettes of Polish political activists as well as women publicly active outside Poland were presented many times.

Keywords: women's press, Kobieta i Życie, Polish People's Republic, International Year of Women, women in public sphere, women in politics

\section{Uwagi wstępne}

Po utworzeniu Polskiej Zjednoczonej Partii Robotniczej w 1948 r. nastąpił intensywny proces centralizacji wszystkich sfer życia politycznego, ekonomicznego, społecznego oraz kulturalnego w Polsce. Zjednoczenie ruchu robotniczego wpłynęło również na kształt środków masowej komunikacji, w tym także prasy, która w okresie Polskiej Rzeczypospolitej Ludowej stanowiła jeden $z$ najważniejszych elementów oddziaływania na społeczeństwo. Czasopisma zostały skupione w głównym państwowym wydawnictwie należącym do PZPR - Robotniczej Spółdzielni Wydawniczej „Prasa”. W 1951 r. przejęło ono od innych spółdzielni wydawniczych kil-

\footnotetext{
1 W pierwszych latach powojennych organizowaniem kolportażu i rozprowadzaniem prasy zajmowało się ponad 30 instytucji wydawniczych. Główną rolę odgrywały Spółdzielw 1947 r. W 1948 r. powstała Spółdzielnia Wydawnicza „Książka i Wiedza” z połączenia się Spółdzielni Wydawniczej „Wiedza”. W tym samym roku RSW „Prasa” połączyła się z pionem prasowym „Wiedzy”, a dwa lata później przejęła pion prasowy „Czytelnika”. Od tej pory RSW „Prasa” stała się największym wydawnictwem prasowym w Polsce. Początkowo zdecentralizowany kolportaż uniemożliwiał prowadzenie jednolitej polityki prasowej. W zwiazku z tym w 1950 r. Prezydium Rządu PRL powołało wielozakładowe
} nia Wydawnicza „Czytelnik” oraz Robotnicza Spółdzielnia Wydawnicza „Prasa” powstała
\end{abstract}


ka najpopularniejszych periodyków kobiecych, w tym m.in. „Modę i Życie Praktyczne” oraz „Kobietę”. W tym samym roku Zarząd Główny RSW „Prasa” podją decyzję o połączeniu obu czasopism i utworzeniu „Kobiety i Życia Praktycznego”. W 1953 r. tytuł uległ skróceniu do „Kobiety i Życia" ${ }^{2}$. Periodyk był jednym $z$ najpopularniejszych czasopism kobiecych okresu PRL ${ }^{3}$. Ukazywał się niemal nieprzerwanie ${ }^{4}$ do 2002 r., kiedy to pismo, nie potrafiąc dotrzymać tempa ówczesnym zmianom na rynku prasowym, zostało zawieszone. W 2008 r. „Kobieta i Życie” ponownie ukazała się w sprzedaży i jest aktualnie dostępna na rynku prasowym.

Od 1953 r., kiedy to czasopismo ukazywało się pod aktualnym tytułem „Kobieta i Życie”, większość publikowanych w nim tekstów była typowa dla prasy kobiecej. Eksponowane zagadnienia skupiały się wokól problematyki mody, urody, macierzyństwa oraz gospodarstwa domowego. W okresach zwiększonego zainteresowania władz gospodarka państwowa szczególnie mocno upowszechniano tematykę aktywności zawodowej kobiet. Istotna zmiana $\mathrm{w}$ doborze poruszanej problematyki nastapiła wraz z początkiem lat 70 . XX w. Wówczas coraz więcej publikacji na łamach „Kobiety i Życia” dotyczyło statusu społecznego kobiet, ich pozycji w przestrzeni publicznej, także w życiu politycznym kraju. Nieoceniony wpływ na tę sytuację miała Barbara Sidorczuk. Nowa redaktor naczelna wprowadziła znaczace zmiany w sposobie redagowania i doborze odpowiednich publikacji. Oprócz kobiet spełniających się w roli matki, żony czy opiekunki domowego ogniska w opisach zaczęły się po-

przedsiębiorstwo kolportażowe o nazwie Państwowe Przedsiębiorstwo Kolportażu Prasy i Książki „Ruch”. W 1973 r. w wyniku połączenia ze Zjednoczeniem Upowszechniania Prasy i Książki „Ruch” koncern zmienił nazwę na RSW „Prasa-Ksiażka-Ruch”, a na mocy ustawy sejmu uzyskał prawo wyłączności kolportażu krajowych i zagranicznych wydawnictw periodycznych.

2 Zofia Sokół, Prasa kobieca w Polsce w latach 1945-1995, (Rzeszów : Wydawnictwo Wyższej Szkoły Pedagogicznej, 1998), 98-101; Małgorzata Dajnowicz, „Kobiety w polityce w wypowiedziach prasowych Krystyny Kaszuby na łamach "Kobiety i Życia" (1985-1990)", w: Ewa Maj, Ewelina Podgajna, Anna Szwed-Walczak, Łukasz Jędrzejski (red.), Komunikowanie polityczne, (Lublin : Wydawnictwo UMCS, 2017), 200; Eadem, „Wzorce aktywności publicznej kobiet w początkach transformacji ustrojowej w Polsce w świetle "Kobiety i Życia» i "Urody» (1989-1995)”, w: Teresa Kulak, Małgorzata Dajnowicz (red.), Drogi kobiet do polityki (na przestrzeni XVIII-XXI wieku), (Wrocław : Wydawnictwo Chronicon, 2016), 420. 3 Grzegorz Wójcik, „Emancypacja kobiet w okresie lat 60. i 70. na łamach czasopisma "Kobieta i Życie»", Kultura Popularna, nr 2(40), 2014, 119.

4 Krótka przerwa w wydawaniu pisma spowodowana była wprowadzeniem stanu wojennego w 1981 r. Jego reaktywacja nastapiła w kwietniu 1982 r. Również w sierpniu 1989 r. na dwa tygodnie wstrzymano druk „Kobiety i Życia”, co związane było z ówczesnymi problemami z papierem, który w PRL był ściśle reglamentowanym towarem deficytowym. 
jawiać sylwetki Polek aktywnych publicznie w różnych sferach: oświaty, nauki, pracy zawodowej czy polityki.

Od początku lat 70. w „Kobiecie i Życiu” coraz częściej pisano nie tylko o sytuacji Polek, lecz także kobiet zamieszkujących inne części świata. Bez wątpienia było to konsekwencją ówczesnych zmian na scenie politycznej kraju i objęciem funkcji I sekretarza Komitetu Centralnego PZPR przez Edwarda Gierka. Starał się on eksponować odmienność nowej władzy od poprzedniej, w wyniku czego prasa stała się „otwarta na Zachód”, a na łamach „Kobiety i Życia” coraz częściej zaczęły się pojawiać teksty korespondencyjne $z$ zagranicy.

Duży wpływ na upowszechnianie tematyki zwiąanej $z$ aktywnością kobiet w przestrzeni publicznej, nie tylko $z$ Polski, lecz także $z$ innych odległych zakątków świata, wywarł rok 1975, który Organizacja Narodów Zjednoczonych ogłosiła Międzynarodowym Rokiem Kobiet ${ }^{5}$. Zgodnie z zaleceniami ONZ miał być poświęcony działaniom zmierzającym do zrównania pozycji kobiet $z$ mężczyznami w życiu politycznym, społecznym, ekonomicznym i kulturalnym. W związku $z$ obchodami Międzynarodowego Roku Kobiet redakcja czasopisma podjęła próbę oceny dotychczasowej działalności poszczególnych władz państwowych na rzecz udziału kobiet $\mathrm{w}$ sferze publicznej. Zwrócono uwagę, że był on niewystarczający w ciałach ustawodawczych, wykonawczych oraz w strukturach partyjnych.

W artykule przedstawiono problematykę aktywności publicznej kobiet, głównie w sferze polityki, prezentowaną na łamach „Kobiety i Życia" w latach 70. XX w. Ponadto przeanalizowano zagadnienia ukazywane w piśmie przy okazji obchodów Międzynarodowego Roku Kobiet. Niniejsze opracowanie stanowi próbę odpowiedzi na pytania: W jakim stopniu ustanowienie przez Organizację Narodów Zjednoczonych roku 1975 Międzynarodowym Rokiem Kobiet wpłynęło na upowszechnianie działalności kobiet w sferze publicznej naszego kraju oraz innych części świata? Czy początek lat 70. XX w. można uznać za okres przełomowy z punktu widzenia popularyzowania aktywności publicznej kobiet w Polsce?

\footnotetext{
5 W 1972 r. Zgromadzenie Ogólne ONZ proklamowało rok 1975 Międzynarodowym Rokiem Kobiet. Na posiedzeniu plenarnym odbywającym się 18.12.1972 r. postanowiono, że 1975 r. poświęcony zostanie sprawom równości kobiet i mężczyzn oraz zwróceniu uwagi na zaangażowanie i wpływ kobiet na rozwój świata - szczególnie poprzez podkreślenie ich ogromnego wkładu w rozwój gospodarczy, społeczny i kulturalny, zarówno na poziomie krajowym, regionalnym, jak i międzynarodowym. Dodatkowo wszelkie działania Międzynarodowego Roku Kobiet miały służyć uznaniu wzrastającej roli kobiet w rozwoju przyjaznych stosunków między państwami oraz ich działaniom na rzecz umacniania pokoju na świecie.
} 


\section{Międzynarodowy Rok Kobiet na łamach „Kobiety i Życia”}

Intensyfikacja tematyki politycznej w „Kobiecie i Życiu” wystąpiła w 1975 r., przy okazji obchodów Międzynarodowego Roku Kobiet. Wówczas po raz pierwszy na większa skalę redakcja periodyku podjęła problematykę małego udziału kobiet w gremiach władzy. W 1975 r. na łamach pisma opublikowano cykl Czy ona jest gorsza?, w którym dyskutowano na temat pozycji kobiet w przestrzeni politycznej. W „Kobiecie i Życiu” pisano: „Dwie kobiety na stanowiskach wiceministrów. Na 2362 naczelników gmin w marcu br. 103 było rodzaju żeńskiego, wśród 403 naczelników miast i dzielnic - ledwie kilka, wśród wojewodów i prezydentów nie ma ich w ogóle"6. Jednocześnie zastanawiano się nad niska obecnością kobiet na stanowiskach kierowniczych: „I znów - w administracji terenowej kobiety są potężną większościa, niektórzy powiadaja, że na nich trzyma się administracja. Ale na kierownicze stanowiska nie zasługują. W awansach politycznych Polkom też nie dzieje się najlepiej, widać je najczęściej na niższych piętrach organizacyjnej działalności"”.

W czasie Międzynarodowego Roku Kobiet redakcja pisma ubolewała nad niskim poziomem aktywności kobiet w polityce. Mówiono m.in. o tym, że w skład najwyższych organów władzy i administracji państwowej w Polsce wchodziła stosunkowo mała liczba kobiet. Przywoływano, że najwyższą funkcja pełniona przez kobiety była funkcja członka Rady Państwa oraz wicemarszałka sejmu. Odnoszono się do danych z 1974 r., pisząc, że wówczas nie mieliśmy żadnej kobiety na stanowisku ministra, jedynie dwie były wiceministrami. Reprezentacja kobiet w sejmie również nie była imponujacca. W Sejmie VI kadencji (1972-1976) zasiadały 73 posłanki, co stanowiło 15,9\% całego składu Izby. Materiał, który był przedrukiem referatu Romana Wieruszewskiego (z Zakładu Teorii Państwa i Prawa Uniwersytetu im. Adama Mickiewicza), zakończony był niezbyt optymistycznym zdaniem: „Aktualnie kobiety nie zajmują jeszcze równej z mężczyzna pozycji w reprezentacji politycznej naszego społeczeństwa"ষ.

Debata na temat stopnia zaangażowania kobiet w działalność polityczną zakończyła się mało optymistycznymi wnioskami, iż równość polityczna kobiet i mężczyzn w ówczesnym społeczeństwie polskim nie istniała. W związku $z$ tym redakcja periodyku za jeden $z$ głównych ce-

\footnotetext{
„Czy ona jest gorsza?”, Kobieta i Życie, nr 26, 1975, 2.

Ibidem.

8 „Czy ona jest gorsza? Równość i równouprawnienie”, Kobieta i Życie, nr 33, 1975, 2-3.
} 
lów wyznaczyła sobie mobilizację Polek do zainteresowania się polityka. Służyć temu miały prezentowane w kolejnych wydaniach wizerunki konkretnych kobiet posłanek, kandydatek do sejmu czy rad narodowych ${ }^{9}$. Zespół redakcji „Kobiety i Życia” uznał, iż przedstawianie działalności aktywnych publicznie Polek zwiększy zainteresowanie czytelniczek tą tematyka.

Oprócz prezentowania sylwetek Polek podejmujących działalność polityczną na łamach periodyku publikowano także materiały, w których ukazywano kobiety zajmujące się polityką w innych państwach. W „Kobiecie i Życiu" przedstawiano dokonania kobiet-polityków z krajów ZSRR, np. Tamary Chetagurowej - przewodniczącej Rady Najwyższej u podnóża Kaukazu czy Tamary Kałłowej - przewodniczącej kołchozu „Kaukaz” ${ }^{10}$. O prezydent Chetagurowej pisano:

Ma rodzinę i dom, jak inne osetyńskie matki i żony, czasem piecze „alibach”, ulubiony przysmak narodowy: ciasto nadziewane owczym serem, ale do pracy jeździ reprezentacyjna limuzyna. Występuje na różnego rodzaju zgromadzeniach, jej fotografie często spotyka się na pierwszych stronach miejscowych gazet. Przewodniczy posiedzeniom Rady Najwyższej. Na wysokim urzędzie pozostaje przede wszystkim kobieta. Kiedy rozmawiamy o sukcesach gospodarczych małej republiki, nie omieszka podkreślić, że najlepszy rynek owocowo-warzywny w całym Związku Radzieckim jest tutaj. Jej rodacy mówią o niej „nasza pani prezydent"11.

\footnotetext{
9 Należy zwrócić uwagę, iż sylwetki kobiet kandydatek do sejmu i rad narodowych znacząco się od siebie różniły, przede wszystkim poziomem wykształcenia. Kobiety starające się o mandat poselski $z$ reguły miały znacznie wyższe wykształcenie od swoich koleżanek kandydujących do rad narodowych. Wśród wizerunków kobiet, niedoszłych posłanek parlamentarnych, dominowały osoby mogące się poszczycić dyplomem wyższej uczelni. Były to głównie lekarki, prawniczki, czyli kobiety wykonujące profesje związane $z$ dużym zaufaniem i uznaniem społecznym. $Z$ kolei kandydatki do rad narodowych zazwyczaj były absolwentkami szkół średnich i zawodowych. Pracowały jako nauczycielki, pielęgniarki oraz pracownice fizyczne. Ponadto kandydatki do sejmu wyróżniały się doświadczeniem w zakresie działalności publicznej. Wiele $z$ nich wcześniej piastowało kierownicze stanowisko albo ubiegało się o reelekcję. Kobiety chcace być członkiniami rad narodowych czerpały natomiast swoje doświadczenie w aktywności publicznej poprzez działalność w lokalnych społecznościach. Urszula Ćwik, „Wybory parlamentarne i wybory do rad narodowych w Polskiej Rzeczypospolitej Ludowej na łamach "Kobiety i Życia" (do 1989 roku)", w: Małgorzata Dajnowicz, Adam Miodowski (red.), Polityka i politycy w prasie XX i XXI wieku, (Białystok : Wydawnictwo Humanica, 2016), 334.

10 Wiesław Sobiecki, „Pani prezydent”, Kobieta i Życie, nr 20, 1974, 6-7.

11 Ibidem.
} 
W dalszej części materiału opublikowanego w 1973 r. podkreślano, iż we wszystkich krajach ZSRR kobiety, które dotychczas pozostawały poza wskazanym statusem społecznym, zaczęły obejmować poważne stanowiska państwowe. Wymieniano, iż pełniły funkcje ministrów, dyrektorów przedsiębiorstw oraz przewodniczących kołchozów. Sprawowanie publicznych posad przez kobiety w latach 70 . XX w. uznane zostało przez autora tekstu za zjawisko charakterystyczne dla ówczesnego okresu w ZSRR i traktowane było jako swoisty przejaw „rekompensaty za wielowiekową dyskryminacje" ${ }^{\prime 2}$. Przypuszczać należy, że tekst ukazujacy wysoki poziom aktywności politycznej wśród kobiet zamieszkujących państwa ZSRR miał stanowić dowód realnego wdrażania zasady równouprawnienia kobiet i mężczyzn za wschodnią granicą. Zamieszczenie materiału o takim charakterze wpisywało się w ówczesną linię propagandy partyjnej, której przejawem było zachęcenie kobiet do łączenia sprawowania funkcji w przestrzeni domowej i publicznej.

Pod koniec lat 70. w „Kobiecie i Życiu” publikowano już nie tylko wizerunki kobiet aktywnych politycznie w krajach ZSRR, lecz także w innych częściach świata, m.in. w państwach skandynawskich. W 1977 r. redakcja periodyku zamieściła obszerny reportaż na temat pozycji kobiet w Norwegii oraz ich reprezentacji w najwyższych gremiach tamtejszej władzy. Relacjonowano, iż w socjaldemokratycznym rządzie Norwegii wśród szesnastu ministrów były cztery kobiety. Pomimo tego, że pod koniec lat 70. XX w. nie był to kraj powszechnie pracujących kobiet, to udział we władzach przedstawicieli obu płci był tam na porządku dziennym. Na łamach periodyku przytaczano słowa opublikowane w rządowym raporcie tzw. Białej Księdze: „Naszym celem jest społeczeństwo o pełnej równości między mężczyzną i kobietą w rodzinie, w pracy i w życiu społecznym. Mężczyźni i kobiety winni mieć te same możliwości wyboru wykształcenia, zawodu i sposobu życia"13.

W dalszej części reportażu jego autorka przytoczyła rozmowę przeprowadzona $z$ Annemarie Lorentzen - minister administracji i ochrony konsumentów oraz Ruth Ryste - minister polityki socjalnej. Annemarie Lorentzen zapewniała rozmówczynię, iż w Norwegii nie było takiej sytuacji, żeby ktoś stawał kobietom na drodze do kariery politycznej. Z kolei

\footnotetext{
12 Ibidem.

13 Agnieszka Wróblewska, „Czy ma pani ambicje? Korespondencja własna z Norwegii”, Kobieta i Życie, nr 6, 1977, 18.
} 
Ruth Ryste zwróciła uwagę, że od 1949 r. już jako piąta kobieta w historii kierowała pracami ministerstwa polityki socjalnej ${ }^{14}$.

Szczególnie dużo miejsca $\mathrm{w}$ periodyku poświęcono Margaret Thatcher. Po raz pierwszy pisano o niej w 1976 r., kiedy objęła kierownictwo partii konserwatywnej w Wielkiej Brytanii. Zastanawiano się nad kierunkiem zmian, jakie wprowadzi do polityki nowa przywódczyni brytyjskich konserwatystów. Jednocześnie redakcja pisma wyrażała się z podziwem o jej karierze politycznej, piszac:

Pani Thatcher ujawniła się $\mathrm{w}$ minionym dziesięcioleciu jako polityk niesłychanie reakcyjny, walczacy przeciwko egalitaryzmowi w szkolnictwie; była ministrem oświaty w gabinecie Heatha. Kiedy konserwatyści przeszli do opozycji, zajęła w "gabinecie cieni” sprawy finansów i zasłynęła jako pełna erudycji, zimna i bezwzględna oponentka labourzysty, Healeya ${ }^{15}$.

Poza słowami uznania dla kwalifikacji i doświadczenia Margaret Thatcher zwracano uwage na ogromne znaczenie ogólnospołeczne jej wyboru na przewodnicząca partii. Podkreślano, że zmiana personalna na tym stanowisku była potwierdzeniem przemian jakościowych w zakresie obecności kobiet w polityce, jakie zachodziły na Zachodzie. Optymistycznie stwierdzono: „Co oznacza kariera tej kobiety? Chyba to, że niepostrzeżenie sprawy płci przestały w sposób bezwzględny określać los człowieka, determinować na przykład rodzaj jego kariery"16.

Najważniejsze wydarzenia $\mathrm{z}$ kariery politycznej Margaret Thatcher znajdowały odzwierciedlenie w kolejnych publikacjach „Kobiety i Życia”. W 1979 r. relacjonowano przebieg kampanii wyborczej partii konserwatystów do parlamentu oraz starania podejmowane przez Margaret Thatcher na drodze do uzyskania stanowiska premiera Wielkiej Brytanii. Zwracano uwagę, że kampania wyborcza z 1979 r. była najbardziej zacięta od czasów zakończenia wojny, co wynikało również z faktu, że nigdy wcześniej sytuacja ekonomiczna Wielkiej Brytanii nie prezentowała się tak źle. W materiale prasowym zaznaczano, iż Margaret Thatcher wykazała się profesjonalizmem, rzeczowo przedstawiając program wybor-

\footnotetext{
14 Ibidem.

15 „Pani Thatcher i co dalej”, Kobieta i Życie, nr 11, 1975, 15.

16 Ibidem.
} 
czy swojej partii. Dodatkowo autor tekstu podkreślał zachowanie męża kobiety, który:

z rzadka i jakby zajęty czym innym pojawiał się podczas jej publicznych wystapień. Wiadomo, że udzielał jej pełnego poparcia i życzył (jak widać owocnie) zwycięstwa. Ale nie chciał, albo ona nie chciała, żeby cokolwiek miało przyćmić siłę argumentacji jej słów; głosujcie na mój program, zdawała się mówić, a nie na mojego męża ${ }^{17}$.

W 1975 r. na łamach „Kobiety i Życia” opublikowano cykl wywiadów przeprowadzonych $z$ działaczkami ruchów kobiecych $\mathrm{w}$ innych częściach świata. Pisano:

Międzynarodowy Rok Kobiet to świetna okazja, aby przybliżyć naszym Czytelnikom sprawy żywotne dla kobiet $z$ odległych stron świata. Mało wiemy o kłopotach Azjatek, Afrykanek czy Australijek. Będziemy pod ta winieta publikować rozmowy redakcji $z$ działaczkami tych krajów, w których życie wygląda inaczej niż u nas i o co innego niż u nas walczy ruch kobiecy ${ }^{18}$.

Szczególnie mocno eksponowano problematykę dotyczacą mieszkanek krajów rozwijajacych się, w których status kobiet i ich położenie ekonomiczne były na najniższym poziomie. Należy zwrócić uwagę, iż publikacje zamieszczane w periodyku były odzwierciedleniem rzeczywistych kierunków działań podejmowanych przez Organizację Narodów Zjednoczonych w ramach Międzynarodowego Roku Kobiet. W 1975 r., jak również w całym kolejnym dziesięcioleciu, skupiła się ona przede wszystkim na sytuacji mieszkanek krajów Trzeciego Świata, co w jednej ze swoich wypowiedzi podkreślała także związana $z$ Uniwersytetem Warszawskim Zofia Morecka:

Myślę, że ONZ-owska dekada adresowana była przede wszystkim do krajów Trzeciego Świata. Tam jest dramat. U nas czego by nie powiedzieć o konkretnych sytuacjach, kobiety maja wcale pokaźne osiagnięcia zawodowe, kulturalne, polityczne. Natomiast kobiety Trzeciego Świata nie maja często wręcz elementarnych warunków, by spełniać swe nawet tradycyjne obowiazki ${ }^{19}$.

17 „Gorzej niż mężczyźni rządzić nie będzie. Korespondencja z Wielkiej Brytanii”, Kobieta i Życie, nr 23, 1979, 18-19.

18 „MRK 1975. Przełamywanie tradycji”, Kobieta i Życie, nr 2, 1975, 3.

19 Barbara Brach, „Kwestii kobiecej ciag dalszy”, Kobieta i Życie, nr 15, 1985, 2. 
Rozmówczynie - działaczki ruchów kobiecych z krajów Trzeciego Świata - wśród najważniejszych problemów wymieniały m.in. panujący $\mathrm{w}$ ich państwach głód oraz brak dostępu do edukacji. Vimia Farooqui, pełniąca funkcję sekretarza generalnego Narodowej Federacji Kobiet Indyjskich, mówiła: „Dramatyczny paradoks Indii polega na zderzeniu świetnej przeszłości, która zachwyca pamiątkami architektury, sztuki, literatury, muzyki $z$ tragedią dnia dzisiejszego - głodem milionów ludzi” ${ }^{20}$. Na podobne kwestie zwracała uwage Ayesha Khanam - sekretarz organizacyjny Związku Kobiet Bangladeszu, która podkreślała wysoki przyrost naturalny w swoim kraju, co znacznie wpływało na trudności $z$ wyżywieniem tak dużej liczby mieszkańców. „Najważniejszą sprawą w Bangladeszu w tej chwili to nakarmić 75 milionów obywateli kraju, w którym co roku przychodzi na świat dalsze 2,5 miliona dzieci. Przyrost produkcji rolniczej nie nadaża za przyrostem ludności - głodnych stale przybywa”21. Działaczki ruchów kobiecych $z$ krajów Trzeciego Świata eksponowały kwestię niezaspokojenia elementarnych potrzeb biologicznych ludności ich państw. Wskazywały, iż ówczesna produkcja żywności nie była w stanie zaspokoić potrzeb społeczeństwa, którego liczba ciagle wzrastała. Wielokrotnie mówiono nie tylko o występującym głodzie, lecz także o niedożywieniu wywołującym wycieńczenie organizmu i liczne choroby.

W wywiadach przeprowadzonych $z$ działaczkami społecznymi spoza państw europejskich dużo miejsca poświęcono również kwestii dostępu kobiet do edukacji i możliwości uzyskania wykształcenia. Przedstawicielka hinduskiego ruchu kobiecego wskazywała, że obok trudności żywnościowych równorzędnym problemem była oświata powszechna, w sensie najbardziej podstawowym - miała na myśli naukę czytania i pisania. Według danych przywoływanych przez sekretarz generalna Narodowej Federacji Kobiet Indyjskich aż 85\% kobiet mieszkających $\mathrm{w}$ Indiach było analfabetkami ${ }^{22}$. W podobnym tonie wypowiadała się sekretarz organizacyjna Zwiazku Kobiet Bangladeszu, która jako jedna z nielicznych obywatelek kraju miała wykształcenie. Mówiła: „W Bangladeszu jest tylko 8 kobiet $z$ tytułem inżyniera i kilka lekarek. Poza nimi - kilkadziesiąt kobiet $z$ bogatszych rodów, które ukończyły szkoły średnie i kilka tysięcy - po szkołach podstawowych. Potem - kilkadzie-

20 „MRK 1975. Przybliżyć współczesność”, Kobieta i Życie, nr 7, 1975, 2.

21 Urszula Garbień, „MRK 1975. Apetyt na garstkę ryżu”, Kobieta i Życie, nr 8, 1975, 5.

22 „MRK 1975. Przybliżyć współczesność”, 2. 
siąt milionów analfabetek"23. Innym krajem, w którym odsetek kobiet niepotrafiących czytać i pisać był na wysokim poziomie, pozostawał Iran. Na łamach „Kobiety i Życia” pisano, iż największym i najbardziej ucią̇̇liwym kłopotem irańskiego społeczeństwa był analfabetyzm, szczególnie nagminny wśród kobiet. Podawano, że nawet w stolicy kraju Teheranie, będącym jednym $z$ najbardziej rozwiniętych miast, blisko $40 \%$ ludzi nie potrafiło czytać ani pisać, a wśród nich zdecydowanie więcej było kobiet niż mężczyzn ${ }^{24}$.

W materiałach publikowanych pod szyldem „Międzynarodowy Rok Kobiet 1975” przedstawiano także wizerunki i działalność kobiet zaangażowanych w walkę o poprawę sytuacji mieszkanek danego państwa. Jedna $z$ nich była Emily Naffa, czołowa aktywistka jordańska. Jak pisano w periodyku, ta przedstawicielka Arabskiej Organizacji Kobiet w Jordanii podjęła heroiczną decyzję, rezygnując ze swojego życia osobistego na rzecz działalności politycznej. Podróżowała po świecie, spotykała się z politykami $z$ innych krajów w celu nagłośnienia problemów, $z$ jakimi zmagały się Jordanki. Jej zaangażowanie publiczne nie uzyskało akceptacji ze strony władz, dlatego umieszczono ja na tzw. czarnej liście, co w praktyce oznaczało m.in. zakaz opuszczania rodzimego kraju. Nie zniechęciło to jednak kobiety do kontynuowania działalności. Zaczęła jeździć po jordańskich wioskach i miasteczkach, organizując pomoc dla najbiedniejszych, naukę dla analfabetów i kursy zawodowe skierowane do kobiet ${ }^{25}$.

W innym wydaniu pisma z 1975 r. przybliżono czytelnikom dokonania madame Szarawi - najsławniejszej działaczki egipskiej. Udzielając wywiadu redakcji periodyku, Suza El Nabarawi opowiedziała o początkach egipskiego ruchu kobiecego. Wspominała manifestacje z 1919 r., która była pierwszym zbiorowym i publicznym wystapieniem kobiet domagających się podniesienia swojego statusu społecznego. Demonstracji przewodniczyła madame Szarawi, która następnie została zaproszona do Genewy na Kongres Kobiet. Powrót egipskiej delegacji do kraju miał wymiar symboliczny, o czym mówiła rozmówczyni:

Kiedy wracałyśmy do kraju, w Aleksandrii wsiadłyśmy do pociagu jeszcze w gęstych czarnych zasłonach, ale w Kairze wysiadłyśmy już

${ }^{23}$ Urszula Garbień, „MRK 1975. Apetyt na garstkę ryżu”, 5.

24 Barbara Sidorczuk, „MRK 1975. Iranka wychodzi z domu”, Kobieta i Życie, nr 17, 1975, 4.

25 Ibidem. 
z odsłoniętymi twarzami. Wszyscy, którzy przyszli nas witać - oniemieli. Wierz mi - to był skandal! ... Madame Szarawi miała ogromny prestiż i jej nawet to szaleństwo nie mogło zaszkodzić. Tak więc to ona była pierwszą Egipcjanka, która pokazała światu twarz ${ }^{26}$.

Działalność Związku Kobiet Egipskich zaowocowała utworzeniem w 1924 r. pierwszej w kraju szkoły średniej dla dziewcząt. Z kolei w 1933 r. pierwsze w historii Egipcjanki ukończyły studia wyższe ${ }^{27}$.

Przywoływanie od połowy lat 70. XX w. na łamach „Kobiety i Życia" wizerunków kobiet polityki na Zachodzie niewątpliwie było odbiciem zmian zachodzacych w świadomości społeczeństwa w kwestii aktywności Polek w sferze politycznej. Przedstawianie kobiet na najwyższych stanowiskach władz miało pobudzać czytelniczki periodyku do refleksji nad miejscem kobiet w polskiej przestrzeni publicznej. Jednocześnie chciano je zachęcić do zaangażowania się w działalność pozadomową. Szczególną uwagę należy zwrócić na dużą liczbę materiałów poświęconych Margaret Thatcher, o której poczynaniach politycznych wypowiadano się w samych superlatywach. Biorąc pod uwage jej nieprzychylność do władz bloku ZSRR i otwartą krytykę reżimu socjalistycznego ${ }^{28}$, tym bardziej znaczaca była obecność tekstów jej poświęconych w analizowanym periodyku.

\section{Uwagi końcowe}

Na podstawie analizy zawartości materiałów prasowych publikowanych w „Kobiecie i Życiu” należy stwierdzić, iż intensyfikacja tematyki dotyczącej działalności kobiet w przestrzeni publicznej przypadała na lata 70. XX w. Przed 1970 r. łamy czasopisma były wypełnione zagadnieniami charakterystycznymi dla magazynów kobiecych, oscylujących głównie wokół gospodarstwa domowego, macierzyństwa oraz skupiających się na szeroko rozumianym poradnictwie. Od poczatku lat 70 . wyraźnie zauważalna stała się zmiana doboru poruszanej problematyki. Bez wątpienia należy kojarzyć to $z$ dwoma nazwiskami: Barbary Sidorczuk

${ }^{26}$ Elżbieta Wierzbicka, „MRK 1975. Pół wieku po zdjęciu zasłony”, Kobieta i Życie, nr 36, $1975,5$.

27 Ibidem.

${ }_{28}$ Na początku 1976 r. Margaret Thatcher wygłosiła mowę, w której w ostrych słowach skrytykowała ZSRR, w konsekwencji czego zyskała swój słynny przydomek. Radziecka gazeta rządowa „Krasnaja Zwezda” nazwała ja Żelazna Dama, co zostało szybko rozpowszechnione przez audycję Radia Moskwa. 
i Edwarda Gierka, którzy w 1970 r. zaczynali nowy etap swoich karier zawodowych. Barbara Sidorczuk została redaktor naczelna „Kobiety i Życia”, znacząco zmieniając tematykę upowszechnianą w periodyku. Jednakże nie byłoby to możliwe, gdyby nie zmiany na ówczesnej scenie politycznej i objęcie funkcji I sekretarza KC PZPR przez Edwarda Gierka. W siódmej dekadzie XX stulecia w obliczu konieczności zaciagania kolejnych zagranicznych kredytów Biuro Polityczne KC PZPR rozpoczęło politykę „otwarcia na świat”, w efekcie czego wielu redaktorów naczelnych miało większą swobodę w doborze publikowanych tekstów prasowych.

Problematyka działalności publicznej kobiet szczególnie mocno upowszechniana była na łamach „Kobiety i Życia” w wydaniach z 1975 r. Przy okazji obchodów Międzynarodowego Roku Kobiet zamieszczano materiały prasowe poruszające kwestię małego udziału Polek w gremiach władzy, ukazujące sylwetki kobiet polityków z zagranicy oraz przedstawiające aktywność działaczek światowych ruchów kobiecych na rzecz rozwiązywania bieżących problemów ich społeczności.

„Kobieta i Życie” jako jedno z najpopularniejszych pism kobiecych okresu PRL w dużej mierze pełniło funkcję edukacyjną. Redakcja periodyku poprzez zamieszczanie odpowiednich artykułów starała się podnosić poziom wiedzy swoich czytelników. Było to doskonale zauważalne przy doborze tekstów publikowanych w 1975 r., w których przybliżano dzieje ruchów emancypacyjnych na świecie. Głównym celem wielu materiałów prasowych $\mathrm{z}$ lat $70 . \mathrm{XX}$ w. było mobilizowanie czytelniczek „Kobiety i Życia” do refleksji na temat miejsca kobiet w przestrzeni publicznej naszego kraju. Publikujac odpowiednie artykuły i tzw. dobre wzorce, redakcja starała się także zachęcać kobiety do podejmowania działalności publicznej, w tym głównie politycznej.

Wydarzenia polityczne $\mathrm{w}$ kraju $\mathrm{z}$ poczatku lat 80. zahamowały proces upowszechniania tematyki aktywności politycznej kobiet na łamach czasopisma. W 1980 r. redakcja „Kobiety i Życia” skoncentrowała się na relacjonowaniu bieżących wydarzeń zachodzacych na polskiej scenie politycznej. Od końca lata 1980 r. informowano o kolejnych wydarzeniach politycznych - strajkach, negocjacjach politycznych między strona rządowa i protestujacymi oraz powstaniu Niezależnego Samorządnego Związku Zawodowego „Solidarność”. Prawdopodobnie nigdy wcześniej 
zespół redakcyjny „Kobiety i Życia” nie poświęcił tyle uwagi sytuacji politycznej Polski, co w okresie tzw. karnawału Solidarności ${ }^{29}$.

Ponadto duży wpływ na zawartość „Kobiety i Życia” z początku lat 80. XX w. miała ówczesna sytuacja gospodarcza. Kryzys ekonomiczny, wszechobecny deficyt towarów i usług, frustracja oraz zmęczenie społeczeństwa zdominowały tematykę eksponowana w periodyku. $Z$ kolejnych wydań czasopisma znikną wizerunek kobiety aktywnej publicznie na rzecz zaradnej i oszczędnej gospodyni domowej. Od początku lat 80. redakcja „Kobiety i Życia” skupiła się na poradnictwie m.in. w zakresie porządkowania mieszkań, przygotowywania posiłków czy szycia i naprawy odzieży, jednocześnie niejako przypominajac kobietom o ich podstawowej roli - matki, żony oraz gospodyni domowej.

\section{Bibliografia}

\section{Źródła prasowe:}

Brach, Barbara. „Kwestii kobiecej ciag dalszy”, Kobieta iŻycie, nr 15, 1985, 2. „Czy ona jest gorsza?”, Kobieta i Życie, nr 26, 1975, 2.

„Czy ona jest gorsza? Równość i równouprawnienie”, Kobieta i Życie, nr 33, 1975, 2-3.

Garbień, Urszula. „MRK 1975. Apetyt na garstkę ryżu”, Kobieta i Życie, nr 8, 1975, 5.

„Gorzej niż mężczyźni rządzić nie będzie. Korespondencja z Wielkiej Brytanii”, Kobieta i Życie, nr 23, 1979, 18-19.

„MRK 1975. Przełamywanie tradycji”, Kobieta i Życie, nr 2, 1975, 3.

„MRK 1975. Przybliżyć współczesność”, Kobieta i Życie, nr 7, 1975, 2.

„Pani Thatcher i co dalej”, Kobieta i Życie, nr 11, 1975, 15.

Sidorczuk, Barbara. „MRK 1975. Iranka wychodzi z domu”, Kobieta i Życie, nr 17, 1975, 4.

Sobiecki, Wiesław. „Pani prezydent”, Kobieta i Życie, nr 20, 1974, 6-7.

29 Mianem „karnawału Solidarności” określa się okres od chwili powstania NSZZ „Solidarność" (31.08.1980) do momentu wprowadzenia stanu wojennego (13.12.1981). Szesnaście miesięcy „karnawału Solidarności” charakteryzowało się swoistym etapem dwuwładzy oraz poczuciem największej swobody politycznej w kraju. Nazwa nawiązuje również do panujących wówczas nastrojów wśród obywateli PRL. 
Wierzbicka, Elżbieta. „MRK 1975. Pół wieku po zdjęciu zasłony”, Kobieta i Życie, nr 36, 1975, 5.

Wróblewska, Agnieszka. „Czy ma pani ambicje? Korespondencja własna z Norwegii”, Kobieta i Życie, nr 6, 1977, 18.

\section{Opracowania:}

Ćwik, Urszula. „Wybory parlamentarne i wybory do rad narodowych w Polskiej Rzeczypospolitej Ludowej na łamach "Kobiety i Życia» (do 1989 roku)", w: Małgorzata Dajnowicz, Adam Miodowski (red.), Polityka i politycy w prasie XX $i$ XXI wieku, (Białystok : Wydawnictwo Humanica, 2016), 328-337. ISBN 978-83-946177-0-7.

Dajnowicz, Małgorzata. „Kobiety w polityce w wypowiedziach prasowych Krystyny Kaszuby na łamach "Kobiety i Życia» (1985-1990)", w: Ewa Maj, Ewelina Podgajna, Anna Szwed-Walczak, Łukasz Jędrzejski (red.), Komunikowanie polityczne, (Lublin : Wydawnictwo UMCS, 2017), 199210. ISBN 978-83-7784-936-1.

Dajnowicz, Małgorzata. „Wzorce aktywności publicznej kobiet w poczatkach transformacji ustrojowej w Polsce w świetle "Kobiety i Życia" i "Urody" (1989-1995)", w: Teresa Kulak, Małgorzata Dajnowicz (red.), Drogi kobiet do polityki (na przestrzeni XVIII-XXI wieku), (Wrocław : Wydawnictwo Chronicon, 2016), 417-443. ISBN 978-83-946166-2-5.

Sokól, Zofia. Prasa kobieca w Polsce w latach 1945-1995, (Rzeszów : Wydawnictwo Wyższej Szkoły Pedagogicznej, 1998). ISBN 83-87288-46-2.

Wójcik, Grzegorz. „Emancypacja kobiet w okresie lat 60. i 70. na łamach czasopisma "Kobieta i Życie»", Kultura Popularna, nr 2(40), 2014, 118 129. DOI 10.5604/16448340.1132098. 